\title{
HISTÓRIA DO DESIGN
}

\author{
Helena Rugai Bastos - helena@acordodesign.com.br - helenarugai@gmail.com
}

Centro Universitário Senac, SP

O Bacharelado em Design do Centro Universitário Senac São Paulo é um curso com duração de 4 anos, em regime seriado semestral e carga horária de 2808 horas. A instituição oferece 3 linhas de Formação Específica na área, a saber: Design Gráfico, Design Industrial e Design Digital. 0 curso de Design Gráfico oferece anualmente 150 vagas, sendo 100 no período matutino e 50 no noturno.

O curso é estruturado a partir de quatro eixos: Formação Geral; Linguagens e Meios de Representação; Projeto do Design; Teórico-prático.A História do Design, oferecida no 2 o semestre do curso, faz parte do conjunto de componentes curriculares do eixo de Formação Geral, que é constituído por disciplinas que abordam conteúdos básicos e específicos relacionados com o campo do design, que promovem a formação cultural, humanista e para a pesquisa. Tais componentes curriculares abordam conceitos sobre o design, promovendo a fundamentação teórica sobre o campo, sobre a comunicação, apresentam relações com outras áreas do conhecimento e buscam desenvolver a visão histórico-crítica e a consciência sobre a atuação dos profissionais da área no contexto em que vivemos. Fazem parte deste grupo, disciplinas como Sociologia, Filosofia, Antropologia, Cultura Material, Metodologia da Pesquisa, História da Arte, Teoria do Design, História da Tipografia, Teoria da Comunicação e da Informação, Design e Sustentabilidade, Teoria da Cor, Gestão em Design, Ética e Legislação, entre outras.

Levando em conta as recomendações expressas nas Diretrizes Curriculares Nacionais para os cursos de Design e o caráter interdisciplinar na área, os componentes curriculares se articulam, estabelecendo imbricações entre os eixos de formação e relações entre as disciplinas e áreas do conhecimento, entre teoria e prática. Desta maneira, as disciplinas não se esgotam em área única. Pelo fato de abordar questões relacionadas à prática do design, à linguagem, às técnicas e aos processos representação e de produção, às tecnologias aplicadas, a disciplina História do Design,

Bastos, Helena Rugai. "História do Design", in Anais do 10 Seminário Paulista do ensino da história do design 2014 [= Blucher Design Proceedings, num.3, vol. 1]. São Paulo: Blucher, 2014. 
também participa do conjunto de componentes curriculares, que compõem o eixo de formação intitulado Linguagens e Meios de Representação.

A disciplina História do Design propõe estudar o desenvolvimento das artes aplicadas, do design gráfico na Europa, Estados Unidos e Brasil, desde a Revolução Industrial até a atualidade, apresentando o contexto socioeconômico, político do período e as transformações culturais nesse percurso. Busca contextualizar a produção visual na área e a teoria relacionada, articulando tais conteúdos com os discursos de cada período. Para tanto, promove a reflexão sobre o desenvolvimento da linguagem gráfica e visual na história. Com este propósito, nas primeiras aulas são apresentados conceitos sobre história, sobre o campo do design, apresentando algumas correntes teóricas e considerações sobre o estudo da história do design nos últimos séculos.

O recorte temporal se justifica na estrutura curricular do curso. No 20 semestre a disciplina História da Tipografia aborda contexto e a produção na história da escrita ocidental, o desenvolvimento do alfabeto, dos tipos e dos processos de impressão tipográfica. Desta maneira, é possível estudar a produção do design,partindo da 2a metade do século XIX até a atualidade.

As discussões promovidas, a partir das aulas e da leitura de textos selecionados, procuram levar os alunos a compreender a prática do design relacionada com questões socioeconômicas, políticas, culturais e com o desenvolvimento tecnológico de cada período. Também, busca-se refletir sobre a recepção das práticas e da metodologia do design no Brasil, a adaptação e adequação à realidade brasileira e ao contexto histórico em que se deram tais transferências, levando em conta, em especial, os anos 1950, período em que se inicia a institucionalização do campo no país.

A abordagem na disciplina procura enfatizar a contextualização socioeconômica do design na história, por meio da análise do desenvolvimento das técnicas de representação, tecnologias e linguagem. São apresentadas vertentes e correntes do design nos vários períodos de maneira concomitante, privilegiando as produções nos Estados Unidos e na Europa, em especial Inglaterra, França, Alemanha, Rússia e Itália, além do Brasil. Em cada período, busca-se refletir sobre o papel do design no contexto histórico. Assim, questionam-se temas e aspectossobre: a constituição do campo do design e sua inter-relação com as artes, a arquitetura, as artes aplicadas; o embate entre artes e ciência; o desenvolvimento da tecnologia e a área; o papel socioeconômico e político do design; ornamento; design e linguagem universal; os discursose paradigmas modernistas e a ruptura destes padrões; o papel cultural do design. Com este propósito, são abordados os seguintes conteúdos:

- Conceitos sobre história, design e história do design.

- Design e contexto - papel socioeconômico, político e cultural do design.

- Conceitos e definições sobre modernidade, moderno, modernismo e pós-modernismo. 
- Séculos XVIII e XIX e as vertentes artísticas.

- A industrialização e à crítica à indústria.

- Pré-modernismo, origens da área: o papel social do design.

- Design, industrialização e nacionalismo: arte, comércio e indústria na Alemanha, Inglaterra, Rússia e Estados Unidos.

- Estilo da máquina, correntes construtivistas.

- Vanguardas modernistas e design gráfico.

- Bauhaus, suas influências e repercussões.

- Diferentes visões e contextos do discurso funcionalista na Europa e nos Estados Unidos.

- O desenvolvimento do campo do design e os períodospré e pós 2a Guerra Mundial.

- Design e nacionalismo na Europa, Estados Unidos e Brasil.

- A boa forma, Escola de Ulm, Swissstyle, design universal e a repercussão na Europa, nos EUA e Brasil.

- Crise do funcionalismo, crise do historicismo e do positivismo.

- Movimentos contracultura.

- Princípios pós-modernistas.

- Design, ruptura e desconstrução.

- Anos 1980 e o "novo design".

- Revolução digital.

A avaliação da disciplina é processual e bimestral, realizada a partir da participação dos alunos em sala nas discussões sobre os textos selecionados, e em duas avaliações individuais desenvolvidas em sala sobre o conteúdo abordado. Os alunos também desenvolvem atividades que propõem a análise gráfica de peças como livros, revistas, cartazes, levando em conta o contexto histórico, os recursos, técnicas e linguagem aplicadas, preferencialmente de designers brasileiros.

A discussão sobre o papel social do design e as atividades que propõem a análise da produção visual levam a uma participação mais efetiva dos alunos do curso. As atividades desenvolvidas contribuem para que a maioria dos alunos perceba a articulação entre teoria e prática, bem como a importância da contextualização histórica para a fundamentação de projeto. Neste cenário, boa parte dos alunos admite a importância da relação entre a prática de projeto e a pesquisa da produção do design na história. 


\section{REFERÊNCIAS}

BRASIL. Ministério da Educação. Secretaria de Educação Superior. Referenciais Curriculares Nacionais dos Cursos de Bacharelado e Licenciatura. Brasília, DF, 2010.

BRASIL. Conselho Nacional de Educação. Câmara de Educação Superior. Resolução no 5, de 08 de março de 2004. Aprova as Diretrizes Curriculares Nacionais do Curso de Graduação em Design e dá outras providências.

Diário Oficial da União, Brasília, DF, 15 de mar. 2004, Seção 1, p. 24. Republicada no Diário Oficial da União, Brasília, DF, 1o abr. 2004, Seção 1, p. 19.

CENTRO UNIVERSITÁRIO SENAC. Projeto Pedagógico do Bacharelado em Design. São Paulo, dez. 2011. 